\title{
The Concept of Shiringoma among the Manyika People of Mutasa - Navigating the Misty Horizon between Reality and Gullibility
}

\section{Canisius Mwandayi}

\begin{abstract}
The study is a phenomenological navigation of the indeterminate but much talked about concept of Shiringoma among the Manyika people. The paper begins by defining who the Manyika are and then moves on to look at the practice of kuromba 'acquisition of special powers' at Shiringoma done by some of the Manyika people. While an outsider may easily dismiss, for example, the idea of a dead person restarting a new existence somewhere as a hoax or something gullible, there are some who really believe it is possible. Kuromba is such a complex phenomenon which makes it difficult, if not almost impossible, to tell realistic appearances from those which are not unless one wasc schooled into the art of performing it or once saw it really happen in one's life experience. Pieces of data were collected through interviews and especially through snowballing, as the practices at Shiringoma were largely secretive. This paper argues that although kuromba appears unrealistic to the ordinary Zimbabwean, there is evidence that there are some Manyika people who have been initiated into the cult. Therefore, stories about the practice are not products of people who are gullible enough to believe in superstition.
\end{abstract}

Keywords: Gullibility, Kuromba, Phenomenology, Manyika People

\section{Introduction}

The study is a navigation of the indeterminate but much talked about concept of Shiringoma among the Manyika people. The paper begins by defining who the Manyika are and then moves on to look at the practice of kuromba, 'acquisition of special powers' of Shiringoma amongst some of the Manyika people. 
Given that it is not easy to understand this phenomenon if one is an outsider, the underlying methodological approach used in this study is phenomenology. The main methods of data collection used therein are participant observation and interviews. Some of the conversations emanating from the interviews were recorded verbatim, whereafter an analysis is made of the data collected.

\section{Manyika People}

The term 'Manyika' has a long-recorded history. Back in the $16^{\text {th }}$ century, the Portuguese reported the existence of a territory called Manyika. They thus called the large region around the Manyika Chieftaincy, Manicaland (Ranger 1989: 122). When the British came in the $19^{\text {th }}$ century, they also picked up this historic term and applied it to almost all the inhabitants of that area. However, most people living in this region never thought of themselves as related in any way to the Manyika Chieftaincy.

Prior to the existence of this extended Manyika identity, the concept 'Manyika' can be said to have had at least different meanings. H.H.K. Bhila (1982) tells us that the original historical meaning of Manyika is the people of Chief or King Mutasa. This territory lies to the north and the northwest of the modern-day city of Mutare. Bordering the western side of Chief Mutasa's kingdom was his long-time enemy and competitor for land, cattle, women and slaves: Chief Makoni, who headed the Maungwe kingdom. As a result of the wars between these rivals, the boundaries of the two kingdoms often shifted, thus the best definition of traditional Manyika, according to Bhila, was political rather than geographical. Manyika in this case encompassed all those who at any one time acknowledged the authority of Mutasa and nobody else (Bhila cited in Ranger 1989: 123).

Moving to the second sense in which the term 'Manyika' was used, in the later $19^{\text {th }}$ century, the Portuguese developed and propagated this concept for themselves. They claimed that the then reigning Mutasa chief had made a voluntary submission to them in 1876. As noted by Bourdillon (1998), soon after their arrival on the East African Coast, the Portuguese had heard tales of a very powerful Mutapa ruler who reigned from the Kalahari Desert in the west to the Indian Ocean in the east. Though these tales did not tally exactly with what they found there, it remained true that Mutapa was an influential figure, such that both Muslim and Portuguese traders, missionaries and administrators continued to have dealings with him. 
More significant for the Portuguese was the Barwe State, whose rulers held the dynastic title Makombe. The Barwe actually occupied the country through which the main trade routes from the port to the Sena in the interior passed, thus making it difficult for the Portuguese not to have dealings with the Makombe. After brief missionary activity in this Makombe area, a new Makombe ruler is said to have asked for 'baptismal water', obtained from the Portuguese at Sena, to be used for the accession rituals. Such a gesture was interpreted by the Portuguese as a sign of his subjection to them. The reality, however, is that there was nothing remotely like a religious submission on the part of the Makombe; this 'baptismal water' referred to here was in fact drunk by the new ruler after it had been medicated by a senior spirit medium. The Makombe simply sought to align themselves with the Portuguese against powerful neighbouring chiefs. The readiness of the Makombe to attack Portuguese outposts and block trade routes each time when there was conflict between the two camps shows that the Makombe retained their autonomy. When the Portuguese tried to exercise their supposed authority over the Makombe in the late $19^{\text {th }}$ century, the latter showed their resentment to this interference by coming out in full force against the Portuguese in two wars, finally suffering defeat only in 1917. They thus utilised this as a basis to expand the area of Manyika on their maps. Eventually they had an enormous territory under their influence. As evidenced from the writings of H.H.K. Bhila (cited in Ranger 1989: 123):

On a Portuguese map of 1887 [...] its boundaries extended along the Zambezi from Shupanga to near Tete, then South-west along the Mazoe and South by the Sabi river valley to its junction with the OdziRiver, then along the Musapa and Buzi Rivers to the mouth of the Pungwe. This enormous size of Manyika was evidently fixed by political and commercial considerations. The Mazoe river valley was included because of rumours of abundant alluvial gold. The kingdom of Manyika over which the Manyika rulers [...] exercised authority [...] was a much smaller area.

The Maungwe kingdom, which had once been outside the Manyika territory, also came to be encompassed on this Portuguese map. This was, however, a merely notional and paper definition, for the Makoni chiefs continued to exercise their autonomous sovereignty. To avoid clashes, as noted by Ranger 
(1989), the Portuguese entered into treaties with these Makoni chiefs.

The arrival of the British, as noted earlier, ushered in another sense of Manyikahood. The BSAC, in its effort to gain control of the Pungwe River route, the main waterway to and from Beira, imposed a treaty on Mutasa on 14 September 1890 (Ranger 1989). As is evidently clear, this move was a countermeasure to the Portuguese claims and the condition of the treaty was that no-one could possess land in Manyika without the consent of the BSAC. With the signing of this treaty, the BSAC created its own 'Greater Manyika', the Western boundaries lying deep inside Portuguese territory. However, areas like Maungwe and Mazoe were left out of this new draft of the BSAC.

Having ensured that the Company's frontiers had been fixed, the BSAC went on to break up the Old Manyika kingdom into two administrative districts of Umtali and Inyanga. The colonial administration took upon itself the task of developing a minimalist definition of Manyikahood. Only Mutasa's people and those in his territory were defined as Manyika. Language also became a special characterisation of these people, for the Manyika have a dialect different from other Mashona. The Umtali Native Commissioner Hulley, in pursuit of the same minimalist understanding of Manyikahood, argued that the three Chiefs in the district, Mutasa, Marange and Zimunya, were of quite distinct origins, even though there was a popular tendency to refer to this district as Manicaland (Ranger 1989: 124).

In the case of the Maungwe, the Native Department was concerned to emphasize the distinction between people of that region and Manyikaland. One thing quite certain was that tribally, linguistically and culturally, the people of Maungwe could not in any way be seen as one with the Manyika of Mutasa. It was only much later, in the 1930s, that a diffused sense of Manyikahood was reached and the Maungwe too have generally come to accept being labelled as members of the wide Manyika identity. Some, however, still vehemently deny any links with this Manyika identity.

In my research, however, when I make reference to the Manyika it would be the old sense of Manyikahood I would employ, namely Mutasa's people. Mainly on the basis of dialect and some other cultural traits, I argue that the Manyika of Mutasa are still, up to this day, quite distinct from other tribes found in Manicaland. This, however, is not to say that Manyika as a dialect is only spoken by Mutasa's people, but it is a dialect commonly used by at least around one million people in eastern Zimbabwe and western Mozambique (Bax \& Diercks 2012; Lewis 2009). 


\section{The Search for Survival and Longevity of Life}

Just like the rest of humanity, the Manyika people have since time immemorial been preoccupied with the search for survival and longevity of life in a world full of evil forces that threaten their existence. This search for existence and preservation of their close family members have seen them embark on various initiatives and often breath-taking adventures to ensure that their aspirations are realised. Among the various ways to secure the precious gift of life is the visit by some kundoromba (acquire special powers) at Shiringoma. Kuromba as defined by Kudzai Biri (2012), denotes the act of visiting a traditional healer in order to get medicine (muti), to be feared, to be wealthy, or in any way noteworthy in society.

\section{Shiringoma}

Shiringoma, which is often spelt Cheringoma, is one of the twelve districts found within Sofala, a province located within the central region of Mozambique. According to a report by Mangue and Oreste (1999), the Cheringoma Plateau is covered by miombo woodlands with dry forest and thicket along the lines of numerous contemplative and tall ravine forest trees growing along the ravine floors. In such a forest, as in many other parts of Mozambique, reports Mangue and Oreste (1999), numerous traditional healers (curandeiros) are found. The forest is highly valued as a source of medicinal plants for those traditional healers. Both rural and urban people are said to travel long distances in order to get treatment or to have all their spiritual problems resolved. Given the proximity of Cheringoma to the eastern boarder of Zimbabwe, it may not be surprising therefore to see Samanyika (a person belonging to the Manyika tribe) crossing over to Cheringoma to seek assistance when need arose.

\section{Why Shiringoma?}

Various factors and forces had a play in making people take the bold decision to visit Shiringoma. It is generally believed and accepted among the Manyika people that their elders lived in an era where there was so much competition in terms of kuromba. Each family had to compete for space and life; hence it forced family heads to see to it that they acquire the necessary muti (special powers) that kept their families going. What it meant was that a family that had 
not gone kundoromba was destined for extinction.

While others went kundoromba to ensure the survival of their families, others simply went kundoromba because they did not want kudhererwa (being belittled) by anyone in the society. Their ego caused them not to want anyone to look down upon them. In their conception, other people in the society were supposed to fear them and should not kuvanongedza (point a finger at them). As a result, they would just want to get whatever they liked and force their way through in whatever errands they would be after without anyone standing in their way. According to one of my informants, Mr M.B. Humba (real name withheld), people did not go kundoromba at Shiringoma only, but some went to Zambia and some even as far as the Democratic Republic of Congo (DRC) (Humba, Interview, Sadziwa Shops, 28/07/15). Among the Manyika people, however, Shiringoma remains a popular name, which may be an indicator that the Manyika people preferred this place, probably due to its proximity to their place of habitation, Manyikaland.

Others came to acquire the special powers not necessarily as a result of them going to hunt for them, but by virtue of staying among people who already practised these customs. Taking a cue from the information given by Sekuru Humba, it can be noted that it was not only the community found at Shiringoma that had people who practised mashiripiti (black magic), but it was also found among some communities in Zambia and DRC. As families wandered from one area to the other in the past, either in search of better pastures, land for agriculture or as a result of being displaced by war, at times they would come to settle among people of different cultures and hence tended to copy the life and culture of the autochthonous peoples. Often as the newcomers came to face the harsh reality of life in their newly settled communities, there were always friends who were willing to point them to famous traditional medicine men/women in the community where they could find help in acquiring powers in black magic also.

\section{The Types of Hurombwa 'special powers'}

According to my informants: Gowera, Musombero and Humba (pseudonyms), there are different types of hurombwa:

\section{Kuramba munhu achimuka (Return to life after death)}

This kind of kuromba is whereby a munhu akaromba (a person who has acq- 


\section{Canisius Mwandayi}

uired special powers), has the capacity to come back to life. In the eyes of the community where he/she used to stay, one is considered dead and like any other dead person, he/she is buried. It is after burial that he/she is believed to come back to life, but then appears in a new community far away from the people who knew him/her. It is believed munhu akaromba of this kind may die in Zimbabwe, but acquires a new life either in Mozambique, Tanzania or Zambia. In the new community where he/she re-appears, life starts all over and he/she may get married and beget children until he/she dies again to start another existence in some new community. In this way life goes on and on for him/her. If, however, he/she meets a person from a previous community who knows him/her, then it is believed he/she passes on for forever and that would be the end of his/her kuromba. The informants testified about a known case that happened in Musodza village under Chief Mutasa. They said that there once lived a person by the name Mr Bonda (not his real name) who married into the Tsadotsa family (pseudonymous family name). He passed on and was buried but, on the day following his burial, when people went for rumuko 'inspection of the grave', people saw a big hole in the grave and there were no sign of his remains in the grave (Musombero, Gowera, Interview, Sadziwa Shops 28/07/15).

\section{Upenyu Urefu (Long Life)}

There are some people, according to my informants, who go kundoromba solely with the desire to live a long life beyond what other ordinary human beings live. I was privileged to get first-hand information from Sekuru M.B. Humba, whose father he said had introduced him to this kind of kuromba. Sekuru Humba said that he was born in 1927 and since then he has never known what an injection is nor has he been admitted to any hospital, let alone taken any drug or pill from any modern-day clinic or hospital. On asking whether he had ever been down with malaria or any other common illness he said, 'I stayed in Sagambe where there is malaria and in Kariba where there are tsetse flies but I never got ill' (Humba, Interview, Sadziwa Shops 28/07/15). Upon probing him further whether his children are also preserved like him, he said that none of them had ever gone to hospital, including even his grandchildren. He said he has a daughter married in Zindi area under Chief Mutasa and she had no worries about sending children to a hospital. To cap it all, Sekuru Humba, at 88 years of age, testified that his father was still alive. Sekuru Humba said he was the fifth-born in a family of six and all the siblings 
of his family were also still alive (Humba, Interview, Sadziwa Shops 28/07/15).

\section{Other Forms of Kuromba}

There are various other kinds of kuromba that men go to seek at Shiringoma. These range from muti for luck, mubobobo, 'capacity to sleep with any woman and at any time', mheni, 'lightning', divisi 'magical power to yield bumper harvests', and various other forms. From the information supplied by my informants, it is solely men who go to Shiringoma, leaving their wives behind. Upon return, however, men narrate to their wives what they would have gone kundoromba. Apart from being a general briefing to their partners, this narration serves to let the women know the muko (the do's and don'ts associated with the muti) in case something goes wrong if the operating rules are not followed. In the end, the women become part and parcel of yehurombwa, even though they may not have visited Shiringoma themselves.

\section{Initiation Rites at Shiringoma}

At Shiringoma, those who had committed themselves to kuromba would be prepared (kubikwa) thoroughly so that their bodies became strong. As narrated by Sekuru Humba, mbanda 'a concoction of herbs' is prepared and boiled in a mbiya 'clay pan'. When the contents have cooled, an initiate is made to sit in the mbiya and suck the watery substance therein through the anus until all is finished. In the event that a friend of his comes by during the process, the initiate is covered with a blanket and he can chat with his friend without the latter even knowing that the initiate is undergoing such a rite. Upon completion of this first rite, the initiate is made to drink furofuro remusiko, 'foam prepared from a tree called musiko'. Its purpose is to strengthen the body and remove any bodily impurities so that the initiate would become fit and strong. This final rite marks the end of the initiation rite and the initiate is ready to go on his way (Humba, Interview, Sadziwa Shops 28/07/15).

In the event, however, that the initiate wants kuromba for luck, G. Musombero narrated that at times an initiate is asked to go and touch mushonga/muti in a nearby place and bring that with him to the medicine man. Upon going to the pointed place, the initiate can either see his naked sister or a terrifying cobra waiting to strike. If the initiate has the courage to touch it, the snake is said to turn into a simple stick. This touching process is how the 


\section{Canisius Mwandayi}

kuromba initiation is achieved and accomplished (Musombero, Interview, Sadziwa Shops 28/07/15). What would then follow is muko, which the initiate is expected to adhere to strictly in case some terrifying misfortune may happen to him or his family. In their research on how mental illness is associated with kuromba, Muchinako, Mabvurira and Chinyenze (2013) aver the same when they note that magic charms got through kuromba come with instructions for use, which have to be adhered to strictly so that they can work as intended. Failure or laxness in adhering to the strict operational instructions ( $m u k o$ ) may result in dire consequences, such as illness, for the non-adhering person.

Once initiated and given the mhiko to adhere to, the initiate returns to normal life just like everyone else in the society. While in the eyes of the people he may look ordinary, he now possesses powers and defences that are beyond the ordinary people. Sekuru Humba narrated an ordeal he once faced when someone tried to poison him at a chenura,'bringing home spirit ceremony' of the Nhanhanu family (pseudonym). He recalled that someone became jealous of him because he was good at beating drums and so decided to kill him with poisoned beer. When Sekuru Humba unknowingly received the beer, the moment it came in contact with his lips, he straightaway vomited and he lost two front teeth in the process. When he pointed out that someone had tried to poison him, the culprit ran away (Humba, Interview, Sadziwa Shops 28/07/15).

\section{Analysing the Phenomenon of Kuromba}

When one takes a look at today's society, one realizes that the issue of kuromba is a phenomenon now less talked about, let alone going to Shiringoma. In the past, apparently there was nothing secretive in talking about kuromba, as almost all families engaged in the practice. With the advent of churches, education and the general exodus of the younger generations from rural communities to towns, the issue of kuromba appears to be losing ground. More and more are beginning to view that practice as archaic and diabolic; hence a great number shun it, let alone even talk about it. The reduced popularity of Shiringoma in particular also appears to be the death of vanagodobori (medicine men) who knew the science of mashiripiti (works of wonder) well. With their passing on, those who need their services have to seek that in places other than Shiringoma.

While that may be as it is, the practice of kuromba has not completely faded in today's society and its end does not even promise to be nigh. From time immemorial, and even today, it is part and parcel of human society. No 
matter how churches may disapprove of it as something gullible and diabolic, or how education tries to downgrade it, or even how the younger generations try to cut ties with their rural roots and identify themselves more with towns, it persists. Due to life's challenges, there is a growing trend among the younger generations to go as far as South African kunoromba. Many are known to return from South Africa with different zvikwambos (goblins). This finds echo from Shoko who said zvikwambos originate from South Africa, brought by labour migrants in search of economic survival (Shoko 2012). The identification of South Africa as the source where most of these goblins are bought from was also confirmed by Dube (2011), who noted that 'enterprising vendors' are reportedly 'importing' the super 'dirty' money-making and fortunebringing goblins from neighbouring South Africa. Most of those lazy to work find it a shortcut to become rich by going kunoromba and they are believed to become rich in an instant. Some people, as nicely captured by Dube (2011), increasingly have the guts to dine with the devil and are prepared to eat from the poisoned bowl for only a few riches, a big house and a nice fleet of cars obtained not from their sweat. Thus, while Shiringoma has become less popular among the Manyika people, for some, nothing much has changed in terms of the human desire to acquire special powers to aid them in their daily lives.

Be that as it may, a few things about this concept of kuromba, however, leave an outsider with a lot of questions. It may appear easy to dismiss the idea of a dead person restarting a new existence as a hoax, but how certain could one be that it is not realistic? How real could it be that an 88-year-old man and who happens to be the fifth-born in his family has a father who is still alive up to this day? Are we possibly seeing a re-invention of the days of the Methuselahs who are said to have lived 969 years (Genesis 5: 27)? To those whose hearts are engrossed in the art of kuromba it may appear to be a real world, but how real is this world to an ordinary person not given to this art? Given the complexity of the world of kuromba, one finds that approaching this world is like entering a misty horizon where it is difficult, if not almost impossible, to tell realistic appearances from those which are not. Possibly only those given to the art may be able to give an answer to this complexity.

A number of Africans, however, believe that kuromba is real. People usually take their cue for this from either the long experience of life or at times from the suffering they once encountered as a result of kuromba. This is evidenced even from the responses to a question once raised on the discussion panel of Mugango Radio Station. The presenter posed the question: Kuromba 


\section{Canisius Mwandayi}

kuriko here, munoziva sei, zvinogadziriswa sei ...? 'Is kuromba real, how do you know it and how can it be rectified? (Mugango 2013). To this ques-tion came a lot of affirming answers. Naboth Mukwada, for example, respond-ed: 'Tingarambe sei kuti kuromba hakuna iko kuroiwa kuriko?' (How can we deny the reality of kuromba when there is witchcraft?) (Mukwada cited in Mugango 2013). A more detailed response was given by George Makoni, who said:

kuriko kuromba, kuromba kunoreva kutsvaka mashiripiti anoita kuti ukwanise kuita zvaunoda uchishandisa mishonga inowanzobva kun'anga. Zvinoti huroyi, raki, zvikwambo - kungopa mienzaniso mishoma. Zvinogadziriswa nekutodzidzisa vanhu kuti hazvina pundutso, kuitira kuti vanhu vagare varega kutamba nemoto, tinofanira kudzidzisa rudo kuvanhu, nekuti izvi zvinokonzera matambudziko kune vamwene kuda zvinhu kwako iwe Kune vakatopindawo mazviri, ropa raJesu ndiro rega rinokwanisa kusuka jambwa iri. (kuromba is a reality, kuromba means obtaining magical powers which make one able to what he/she wants using charms which one would have obtained from a traditional healer. The few examples of kuromba are witchcraft, lucky, zvikwambo (goblins), etc. This can be rectified through teaching people that having such powers has no value, so that people do not play with fire. We should teach love to people because this causes unnecessary suffering to others. To those in it already, only the blood of Jesus can wash away this bad misfortune) (Makoni cited in Mugango 2013).

Echoing similar sentiments but veiled in a bit of slang, Takunda Adriano Gushure affirmed, 'ehe kritii bt hazvisi bho' (Yes, it is fully real, but it is not good) (Gushure cited in Mugango 2013). Though not directly responding to the question, but implicitly acknowledging that kuromba is real, Morris Dube commented, 'Vanhu ngavadzidze kuti aromba mangwana rinova dambudzo kuvana vake'. (People need to learn that a person who goes kunoromba will leave behind a problem for his family in the future) (Dube cited in Mugango 2013).

Not everyone, however, would agree that kuromba will be a time bomb for his family. Sekuru Humba, for example, on being asked whether what he did would not spell danger for his family, argued that he had not gone kunoromba to endanger anyone; he had simply done it in order to live long; hence his move meant nothing disastrous at all for his family (Humba, 
Interview, Sadziwa Shops 28/07/15). While Sekuru Humba, on his part, might be genuine, it is still a grey area not to regard kuromba as a time bomb. Cases whereby either some elderly people or the family members of the deceased man demand that they be buried with their 'special suitcases' are not uncommon. Be that as it may, the phenomenon of kuromba remains a misty area to venture into and one can hardly be absolutely certain about it.

\section{Conclusion}

Using first-hand information obtained through some interviews, the discussion has basically centred on the practice of going kunoromba at Shiringoma. As noted in the discussion, while the information about the practice is very scanty and hazy, it is an often talked about phenomenon among the Manyika people. Such discussions about the practice confirm that it used to be done but the how part is what remains vague to many, given that it was practised secretly. The researcher was quite fortunate, in the sense that in his search for information about the practice, he met an informant who happened to have undergone such a practice and was willing to share his experience and knowledge. It was quite enlightening indeed to have a first-hand account of what transpires at such rituals. However, since the Manyika people are popularly known for kusvitsa, 'not letting the cat out of the bag when it comes to essential information', one may not regard the information supplied by my informants as all that has to do with kundoromba at Shiringoma. There may thus be a need to investigate this phenomenon further.

\section{References}

\section{Primary Sources}

Humba, Interview, Sadziwa Shops, 28/07/15.

Musombero, Gowera, Interview, Sadziwa Shops 28/07/15.

(Musombero, Interview, Sadziwa Shops 28/07/15.

\section{Secondary Sources}

Adogame, A., E. Chitando \& B. Bateye 2012. African Traditions in the Study of Religion in Africa: Emerging Trends, Indigenous Spirituality and the 
Canisius Mwandayi

Interface with Other World Religions. Essays in honour of Jacob Kehinde Olupona. Burlington: Ashgate Publishing Company.

Bax, A. \& M. Diercks 2012. Information Structure Constrains on Object Marking in Manyika. Available at:

https://doi.org/10.2989/16073614.2012.737596

(Accessed on 30 July 2015.)

Bhila, H.H.K. 1982. Trade and Politics in a Shona Kingdom. The Manyika and their Portuguese and African Neighbours, 1575 - 1902. London.

Biri, K. 2012. The Silent Echoing Voice: Pentecostalism in Zimbabwe and the Quest for Power, Healing and Miracles. Studia Historiae Ecclesiasticae 38: 37-55.

Bourdillon, M.F.C.1998. The Shona Peoples: An Ethnography of the Contemporary Shona, with Special Reference to their Religion. Gweru: Mambo Press.

Dube, L. 2011. Goblins Demand Outstrip Demand. The Herald. Available at: http://www.herald.co.zw/goblins-demand-outstrip-suppl/

(Accessed on 5 August 2015.)

Lewis, M.P. (ed.). 2009. Ethnologue: Languages of the World. Sixteenth

Edition. SIL International, Dallas, Online Version.

http://www.ethnologue.com (Accessed 6 August 2015.)

Mangue, P.D. \& M.N. Oreste 1999. Non-Wood Forest Products in Mozambique. EC-FAO Partnership Programme (1998-2000) - Project GCP/INT/679/EC Data Collection and Analysis for Sustainable Forest Management in ACP Countries - Linking National and International Efforts. Available at:

http://www.fao.org/docrep/003/x6693e/x6693e02.htm

(Accessed on 7 August 2015.)

Muchinako, G., V. Mabvurira \& P. Chinyenze 2013. Mental Illness and the Shona People of Zimbabwe: Some Key Issues. International Journal of Advanced Research in Management and Social Sciences 2, 3. Available at: http://www.garph.co.uk/ijarmss/mar2013/13.pdf

(Accessed on 10 August 15.)

Mugango, Radio Station. Available at:

https://www.facebook.com/pages/Mugango/368341639945778

(Accessed on 7 August 2015.)

Ranger, T. 1989. Missionaries, Migrants and the Manyika: The Invention of Ethnicity in Zimbabwe. In The Creation of Tribalism in Southern Africa. 
Available at: http://ark.cdlib.org:/13030/ft158004rs/ (Accessed on 10 August 2015).

Shoko, T. 2012. Teaching African Traditional Religions at the University of Zimbabwe. In Adogame A., E. Chitando \& B. Bayeteye (eds.): African Traditions in the Study of Religion in Africa: Emerging Trends, Indigenous Spirituality and the Interface with other World Religions. Essays in honour of Jacob Kehinde Olupona. Burlington: Ashgate Publishing Company.

\section{Dr. Canisius Mwandayi Department of Religious Studies \\ Midlands State University Zimbabwe}

Academic Associate/ Research Fellow Research Institute for Theology and Religion (RITR)

College of Human Sciences University of South Africa (UNISA)

Pretoria

canisiusm@gmail.com mwandayic@staff.msu.ac.zw 